\title{
A User Centred Access Model
}

\author{
Olof Nilsson \\ Mid Sweden University, CITIZYS Research Group, Dept of Information \\ Systems \& Media, Sweden \\ olle.nilsson@miun.se
}

\begin{abstract}
This paper presents a model to assist in the ability to judge access by private persons to the Internet in general, and to Public Information Systems (PIS) particularly. It has its starting point in the Swedish Government's endeavour to turn Sweden into the first 'information society for all'. When the available statistics concerning the access to a PC and the Internet in Swedish homes are studied it is easy to think that this vision may soon be realised. Of course, access to the technical equipment is a fundamental condition in order to be able to use the Public Information Systems, but unfortunately, is not the only one. Several studies have shown that it is not possible to equate possession and use. A number of access models or frameworks designed to judge whether or not a person has access to the ICTs do exist. However, it is my opinion that there is a deficiency in these models; they do not start out from the individual user's prerequisites, but rather judge the external conditions available for possible access. Assisted by four empirical studies, interviews and questionnaires, a number of access barriers experienced by the users have been identified. The studies show that in addition to the technological hindrances, a series of more elusive ones also exist originating from prevailing norms and values in the environment the user lives in. The barriers are categorised into five groups: to have, to be able, to will, to may and to dare. Together these notions form the User Centred Access Model, UCAM, which is suggested for use in charting and communicating the necessary considerations that must be taken into account in the development of Public Information Systems aimed for e-governmental issues.
\end{abstract}

Keywords: User centred access, access barriers, digital divide, information society

\section{Introduction}

A prayer for the information society:

"Dear God:

Please use the following format when citing this chapter:

Nilsson, O, 2006, in IFIP International Federation for Information Processing, Volume 223, Social Informatics: An Information Society for All? In Remembrance of Rob Kling, eds. Berleur, J., Numinen, M. I., Impagliazzo, J., (Boston: Springer) pp. 445-455. 
Please remove the have nots, the can nots, and the do nots that invade my mind.

Please erase the will nots, may nots, might nots that invade my heart.

Please release me from the could nots, would nots and should nots that invade my life." [1]

A number of studies reveal that possession a PC and an Internet connection in your home do not automatically imply that all the members of the household are users [e.g. 2, 3, 4, 5, 6]. Despite this fact, we could find all these individuals in the official statistics as households or citizens with access to an Internet connected PC in their home. This indicates two of the main ideas associated with this paper. The first is that possession, access, and use are notions that we cannot treat as being equal. The second is that circumstances other than the technical ones must come into consideration to be able to judge the options available for citizens to have access to the Internet and the ability to use Public Information Systems, PIS.

A great body of research has pointed out the inequalities in access to IT. I venture to say that it is now possible to have an overall picture of these inequalities. Generally speaking, more men than women have access to the Internet, more young people than elderly, more highly educated than less educated, more employees than unemployed, more rich than poor, and so on [e.g. 6, 7]. It is tempting to draw the conclusion that the inequalities in access to IT do mirror previously existing societal disparities [8]. In order to change these conditions, if indeed it is the ambition to one day achieve the 'information society for all', it is necessary for us to seek understanding for the reasons behind why it appears as it does, i.e. why the user is a user and why the non-user is a non-user. By investigating and understanding these mechanisms or hindrances to access, we are better equipped with the necessary tools to complete or bridge the digital gap.

\section{The Access Concept}

The purpose of this paper is to identify and analyse barriers that affect the individual user's experiences concerning access, and the use of the Internet for personal use. To be able to utilise the technology, access is essential. In this paper, we use the access concept in a somewhat broad perspective, covering all the aspects that we should take into consideration. In addition to the technical, physical and knowledge factors, economic, social, cultural, and mental aspects will be included.

We could either assume that those in households with an Internet-connected computer have access to the Internet. We could also assume that we also must add the possibilities for the household members to use the equipment and to talk about access. Beyond possession and possibility, we also must include the actual use for the given access to obtain the correct picture. Kling et al [9] emphasise that one PC is not equal to another PC, or "ICTs are configurable - they are actually collections of distinct components". This quote implies, that if we are satisfied with the answer if a person has a PC at home or not, we cannot say anything about the purpose of this specific equipment. 


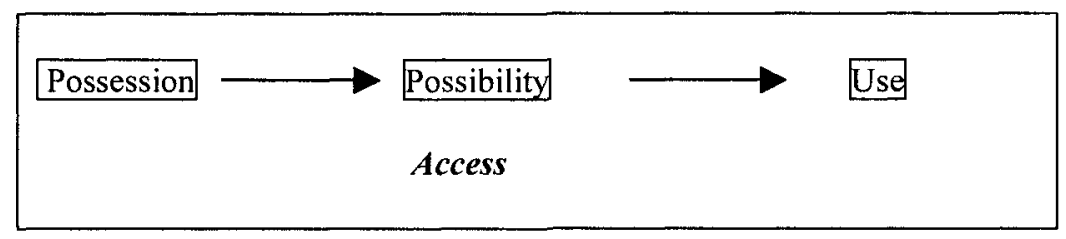

Figure 1: The widened access concept [14]

Clement \& Shade [11] suggest three questions whose answers could assist in the formulation of a feasible description of the access concept, adapted to the actual situation:

1. Access to what? What is it that the individual should have the possibility to use, and how should this possibility be provided?

2. Access for whom? Should this possibility be provided to everyone or merely for specific individuals or groups?

3. Access for what purpose? For what purpose is this possibility provided?

As a starting point for a detailed formulation of a description of access that serves this paper's purpose, use is made of the answers to the above questions. The answer to the 'to what' question, will be access to Internet-based public information and services. Provision should be in a way that does not limit the individual's possibility of using the access. This implies that a computer with an Internet connection at home is a prerequisite for the possibility to use the Internet as a daily tool [15]. The second question, regarding whom, could only have one answer, namely all citizens. In Sweden and in a number other countries (e.g. the UK, Canada, and Australia to mention but a few) this requirement is stated in governmental bills or in other official documents [16]. We could view the purpose of providing the access as two-fold; one is to make it possible for the citizen to take part in their rights and to fulfil their duties in a desired way, and the other to make the public administration less expensive and more effective [17].

Having come this far, consideration must be given as to whom should make the judgement regarding whether or not a person has access. Is it the individual himself or herself who makes a subjective interpretation, or should the judgement be made by anyone else based on a more objective basis? Two different perspectives can be separated out, a 'from-outside' view and a 'from-inside' view.

\begin{tabular}{ll}
\hline From outside & From inside \\
\hline External actors perspective & Individuals perspective \\
What are offered? & What are offered? \\
To who is it offered? & Am I able/allowed to use it? \\
What are the benefits for us? & What are the benefits for me? \\
More objective & Personal, subjective \\
\hline
\end{tabular}

Figure 2: Two different perspectives to study access [14]

It is the opinion of the author that the main part of current research and official reports and statistics is based primarily on the former perspective [e.g. 6, 7]. These reports and statistics have provided a substantial body of knowledge about what 
technology, education, and information offers or provides the individual. It can be stated that it determines the external actors' (i.e. the Internet Service Providers, the companies, the organisations, and the authorities) activities and efforts, and the results in the form of the number of PCs and Internet connections in a country. It also provides demographic information about the users and non-users, and to the extent in which they use it. This knowledge is of course necessary. However, to handle the question regarding how and why the individual uses or does not use the provided technology and its applications, requires a 'from-inside' perspective.

The most commonly used pair of notions to describe the differences in access is that of the 'haves' and 'have-nots' [e.g. 18, 19], which gives information about who has the technology at home and who has not. The shortcoming of this dichotomy is that it merely describes the possible access to IT, which is only one part of the problem. We could also find those who do not can, want, may, or dare use the technology among the non-users. This provides four additional dichotomies namely 'want to' and the 'not want to' or the 'be able to' and the 'not be able to', of the 'be allowed to' and the 'not be allowed to', or finally the 'dare to' and the 'not dare to' people. To be aware of these latter dichotomies is important and has an underpinning by reports that show that possession is not the same as actual use [e.g. 2, 6].

\subsection{Driving Forces or Barriers}

If our goal is to bring about or facilitate a change, it is more fruitful to look forward than backward [20]. The question to answer will then be: What are the hindrances for us to do what we want to do, or why do we act in a way we do not want to? The focus will be to identify and to study the factors and the barriers that the individual experiences as standing in the way of the everyday use of the Internet.

\begin{tabular}{ll}
\hline Driving forces & Barriers \\
\hline Causal & Intentional \\
Looking backwards & Looking forward \\
What made us acting? & What hampers the acting? \\
Tells what has happened & Tells what has to be changed \\
\hline
\end{tabular}

Figure 3: Characteristics for driving forces and barriers [21]

We should not look upon the driving forces and the barriers as dichotomies. The lack of a driving force does not imply a barrier, and similarly, the absence of a barrier does not automatically denote a driving force. For example, a common driving force for Swedes to obtain an Internet connected PC at home is school age children [7], but we should not view being without children as a barrier, only as the absence of a driving force. Israel [20] suggests that we should study hindrances or barriers at five levels. (a) Hindrance concerning our biological equipment and the structure of the physical world should be a mission of technology that often provides a bridge for these obstacles. (b) Existing economic, social, political, and cultural processes in society limits our actions if we are willing to follow the rules and accept sanctions for breaking them. (c) Organisational structures such as the family, school, 
workplace, and organisations where we live and work have obstacles at two levels: (i) the existing social division of labour and the power and authority conditions in these structures' daily function, and (ii) norms and rules in relation to their activities and goals as well as their resources has a limiting function. (d) Interpersonal relations and interaction could bring about two types of hindrances: (i) formal rules and dictated roles that limit actions and (ii) the communication process. (e) Hindrance may originate from the individual's own mind because of fear, uncertainty, or a lack of confidence in his or her own ability.

When we adopt Israel's suggested barriers for this study, we obtain the following categories: 1) Technical barriers; 2) Physical barriers; 3) Economical barriers; 4) Cultural and social barriers; and 5) Mental barriers. In this context, these five categories will generate a necessary sixth one, namely knowledge and skill barriers, used in the following empirical studies to discuss and propose an access model.

We studied and applied four current access models (Aspden and Katz [10], Clement and Shade [11], Poland [12], and Van Dijk and Hacker [13]) to these six categories of barriers, which gave the following result.

\begin{tabular}{lllll}
\hline Barrier & $\begin{array}{l}\text { Aspden \& } \\
\text { Katz }\end{array}$ & $\begin{array}{l}\text { Clement \& } \\
\text { Shade }\end{array}$ & Poland & $\begin{array}{l}\text { van Dijk \& } \\
\text { Hacker }\end{array}$ \\
\hline Technological & & $\mathrm{X}$ & $\mathrm{X}$ & $\mathrm{X}$ \\
Physical & & & $\mathrm{X}$ & \\
Economical & $\mathrm{X}$ & $\mathrm{X}$ & & $\mathrm{X}$ \\
Knowledge and skills & & $\mathrm{X}$ & $\mathrm{X}$ & $\mathrm{X}$ \\
Social and cultural & $\mathrm{X}$ & $\mathrm{X}$ & $\mathrm{X}$ \\
Mental & $\mathrm{X}$ & & $\mathrm{X}$ & \\
\hline
\end{tabular}

Figure 4: Access models applied to the access barriers [14]

As one can see, none of the above mentioned access models cover all of the suggested aspects. Thus, it is necessary to take the process one-step further in the attempt to design a user centred access model, UCAM. We can view the aspects as circumstances that affect the individual's conception of IT, and the extent to which he or she will, can, allowed, and dares to use IT. We have named the barriers in the UCAM with commonplace notions such as have, want, may, able, and dare to make them easier to communicate to people who are outside academia.

\begin{tabular}{cl}
\hline Barriers & Description \\
\hline Have & Technical, physical possibility to use \\
Want & Will to use \\
May & Allowed to use \\
Able & Knowledge to use, economical prerequisites \\
Dare & Familiar to use \\
\hline
\end{tabular}

Figure 5: The user centred access model, UCAM [14] 


\section{Identifying the experienced access barriers}

We made this study as a critical analysis [23] applied on the results from four empirical studies, made in the period October 2001 to May 2005. From these studies developed a number of access barriers identified and categorised in the UCAM as technological, physical, economic, knowledge and skills, and social-culturalpsychological barriers.

We made the first empirical study in the municipality of Härnösand during October and November 2001 [3]. The tool used in the survey was a questionnaire distributed to 500 persons, born 1985 or earlier, of which 400 completed the form. The form contained of 53 questions, of which 52 had fixed answering alternatives. We invited informants to leave comments to any the questions if they felt limited by the fixed alternatives.

The second study was an interview study made among parents of pupils at two schools in two different town districts in Gothenburg, which had taken place at the end of February 2002 [23]. We made the data collection by semi-structured interviews. The two head teachers, ten teachers, one school assistant, one administrator, and two from school healthcare were interviewed individually. In addition, we interviewed 20 parents with children in the 13 to 15 year age category by telephone, and 22 pupils in groups at the schools.

We carried out the third study in April and May of 2003 [14]. The study included 290 parents from 182 families in Härnösand and Gothenburg with children in the 7 to 12 year age category who answered a questionnaire concerning their use of Internet at home.

The last study was an interview study among parents to children in compulsory schools and teachers at the schools in the municipality of Sundsvall [4, 5]. We conducted the parental interviews as focus group interviews [24]. This included 5 interviews with five to six parents in each focus group, and 9 individual interviews with the teachers.

The identified access barriers has been categorised in the five groups or categories. A summary of these hindrances was categorised and applied to the User Centred Access Model in the table below. These categories are not independent of, or isolated from each other; they are rather interdependent. That fact generates a factor that could occur in more than one category, which could affect one or more other factors.

\begin{tabular}{lcl}
\hline Barrier & Experienced hindrances \\
\hline Have & - & Lack of PC; \\
& - & Lack of Internet connection due to infrastructural circumstances; \\
& Lack of Internet connection due to considerations for the own \\
& children; \\
& - & Registration problems; \\
Want & Economic constraints; \\
& - Slow transmission due to bandwidth; \\
& - Unattractive service; \\
& & Anwanted pop-ups and spam;
\end{tabular}


- Unreliable information;

- Lack of use worthiness;

- Lack of interest in the technology;

- Lack of time;

- Gets all necessary information the 'traditional way';

- Threat against the personal contact;

May - Limitations in use opportunity due to the division of the domestic work;

- Limitations in use opportunity due to the number of family members;

- Limitations in use opportunity due to the placing of the equipment;

- Economic constraints;

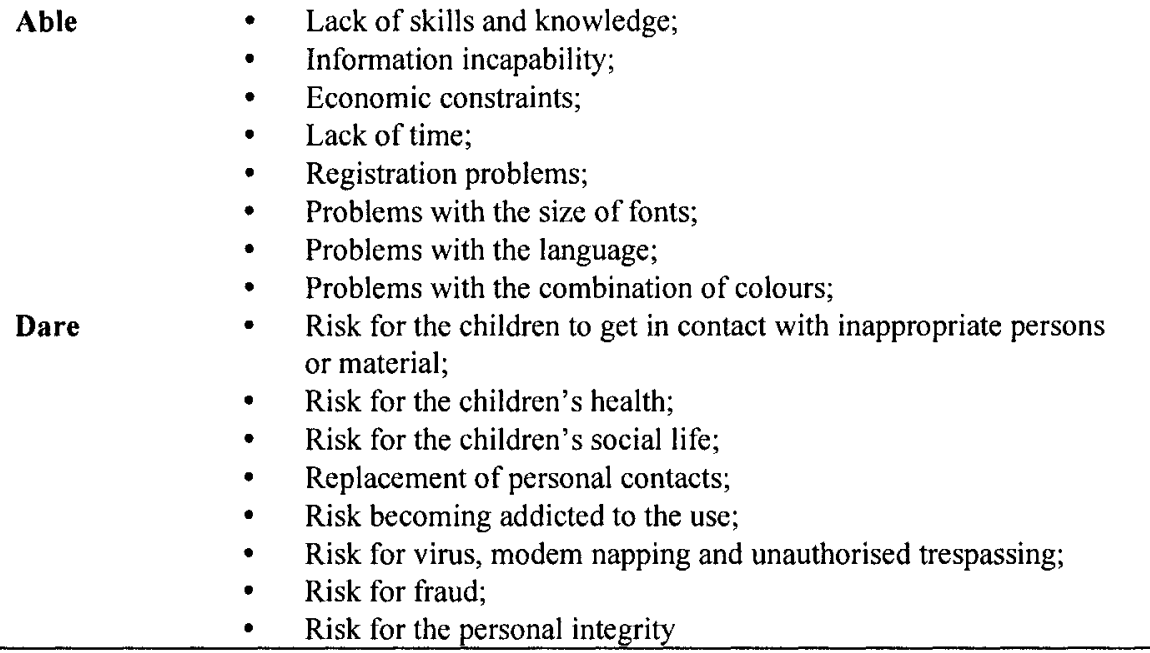

Figure 6: The identified access barriers applied to the UCAM [14]

\section{Discussion and Conclusion}

The first conclusion drawn from the study is that it was possible to use the User Centred Access Model to categorise the identified barriers. We could place all the hindrances experienced by the respondents in the empirical studies in a feasible category. The use of the UCAM also offers the possibility to present the access barriers in a structured way that is easy to understand and communicate with the experts and with the uninitiated.

Later, I will state the identified access barriers, which we can divide into two rough categories or groups according to their origin or causing factors. These two groups are:

- Access barriers whose origins are in, or are caused by the infrastructure, the design of the applications and the equipment, the use and political and economic circumstances. 
- Access barriers that have their origin in, or are caused by prevailing values and norms in society or in the user's environment or own mind.

Constraints (such as the possibilities to obtain a broadband connection, slow modem transmission, old equipment and software, hyperlinks that do not work, virus attacks, and design problems to mention but a few) appear in the first category. We can state that this category of access barriers is not the major problem in the endeavour towards the 'information society for all'. Of course, we cannot ignore them, as we must also accommodate them while obstructing the possibilities to use technology. I base this statement on my firm conviction that today the knowledge and skills are available to remove these access barriers; it is merely a question of money, politics, and will.

The other challenge occurs when the goal is an equal possibility to access and to remove the barriers that exist in an individual's own mind formed by the structures and norms in the social and cultural environment in which we live. LindbladGidlund [25], Bijker and Pinch [26], and Popper [27] showed the shaping and the presence of these individual concepts of technological artefacts as well as the individual's relation to them. These barriers, experienced by the individual, are more difficult to handle when they created from their own feelings, interpretations, and concepts. This does not only concern gender issues, education or income, but also how we regard the way in which we should live our lives, or our form of life, life cycle, and life style as suggested by Selg [2].

In the Swedish Government's bill 1999/2000:86 [16], there are three prioritised areas: the confidence in IT, the competence to use IT, and the accessibility to the services in an information society. The bill also points out where the efforts should lie in order to create the 'information society for all'. When we view the identified hindrances experienced by Swedish citizens in this study, one realises that a great deal of work remains before we cam move the focus from these three prioritised areas. However, we could place all of the identified barriers into the three areas. The study shows that an obvious lack of confidence exists in both the technology and its use among the respondents. I dare to state that this is the most crucial 'piece in the puzzle' that requires full attention and effort. We must view confidence as a subjective factor that is dependent on the individual observer; confidence is also a dynamic factor that could change very quickly. Our ideas concerning the technology are formed, affected, and changed by not only by our own experiences, but also by the environment in which we live. Newspapers, radio and television, strongly influence our trust or distrust in IT. Headlines such as "Giant bluff against Nordea false website panic closed net services" (Aftonbladet, 2005-10-04) will not contribute to making those who feel dubious any more friendly to their own use of technology. Nevertheless, in the same way as media scares the users or the potential users, it also encourages or stimulates them to use technology with lyrical descriptions and stories about different equipment or applications fantastic qualities. For example, in DN (2005-10-19) you could read that the "iPod is the first technical apparatus that makes it possible to carry with you a part of your cultural heritage. An extra memory to your brain that could be filled with that, that have stamped and formed your identity".

Beside the mistrust in the technological artefacts, the applications, and the eventual unwanted consequences, there is also an expressed lack of confidence in 
one's own capability or skill in handling the machine and using the applications. A third experienced area of confidence problems is the reliability of the information and sources associated with the Internet. This result corresponds to the results in the report from the World Internet Institute [28] that shows that 58,7\% of the Swedes trust at least half of the information at the Internet. A common feeling of uncertainty and anxiety was expressed particularly among the female respondents, when it came to risk associated with the use of the Internet. These feelings did not relate to their own use, but to the children's use. Almost $80 \%$ of the Internet users also experienced concerns that the authorities and the employers obtain the possibility for increasing control and supervision [28]. The same study shows that $86,9 \%$ of Swedes are worried or greatly worried about being attacked by a data virus.

A common opinion among the users was that they did not feel that they had sufficient knowledge or skills to feel comfortable in front of the computer. As long as everything worked as it was supposed to work, and everything on the screen looked as it usually looked, there were not many problems. Unfortunately, this idealistic situation is not very common. For many it is sufficient to encounter an unexpected pop-up window or a change in the appearance of the desktop, to feel insecure as to how to act. Many of the confidence problems originate from a lack of knowledge and skills and they will probably decrease as competence levels increase. However, some of them (e.g. the worry to be attacked by a virus is $79 \%$ ) consider themselves very experienced users [28].

Often public access points such as libraries, workplaces, or schools are used as an argument for everyone's possibility to use IT. If you, for one reason or another, do not have the necessary equipment at home, one would expect you to use IT in some other place. The participants in my studies put forward a number of reasons why they did not see these external access points as a realistic alternative for their private use of the Internet and Public Information Systems. The lack of privacy at a public access point limits the services you feel comfortable in using. Additionally, you must also face restrictions to the hours of service, thus reducing the advantages of the $24 / 7$ promoters. At many workplaces, the private use of the Internet is strictly limited either by the employer or by the employees' own conscience. These arguments support Grönlund [15] who states that access to the equipment at home is a requirement to become a daily user.

The occurrence or experience of a specific access barrier is not a static condition; the changes over time and the differences in use between men and women are decreasing [7]. The elderly have always been noted as being a group who have been unfairly treated in this context, but according to a new report from the European Union named eInclusion revisited: the local dimension of the Information Society [29], "the elderly are crossing the digital divide". This is perhaps not so surprising, as the group referred to as 'elderly' is defined as those who are 55 or older and a huge difference exists between a 55-year-old today and one of ten years ago with reference to the options and availabilities offered by the information technology.

I will also draw the conclusion that Israel's suggestion [20] concerning changes of an unwanted situation; it is more fruitful to concentrate on the barriers than the driving forces; the results of this work support this concept. We realize that a number of the access barriers identified here are not possible to overcome simply by means of increased driving forces. The worry many parents feel for their children and the 
lack of design expressed by some users will not decrease by means of a driving force. A driving force could on the other hand, stimulate other barriers such as the lack of reasons for IT use.

\section{References}

[1] [http://beliefnet.com/story/95/story_9522_1.html]

[2] H. Selg, Vem använder Internet och till vad? Spridning av Internet bland befolkningen, IT-kommissionens rapport 1/2002, SOU 2002:24, Stockholm, Sweden, (2002)

[3] O. Nilsson, The use of, and access to PC, Internet and a local government's web site - $A$ study of a strategic chosen group of residents in Härnösand - in Proceedings of Promote IT Conference 2002, Skövde, Sweden (2002)

[4] O. Nilsson, Vardagskommunikation skola-hem, delrapport 2, Sundsvalls Kommun rapport 2005:4, Sundsvall, Sweden (2005)

[5] O. Nilsson, Sefyrin, J. Vardagskommunikation skola-hem, delrapport l, Sundsvalls Kommun rapport 2005:2, Sundsvall, Sweden, (2005)

[6] O. Findahl, Svenskarna och Internet 2003, World Internet Institute, Gävle, Sweden, (2004)

[7] SCB, Use of computers and the Internet by private persons in 2004, SCB, Stockholm, (2004),

[http://www.scb.se/statistik/_publikationer/IT0102_2004A01_BR_TKFT0404.pdf]

[8] B. Barber, Open lecture at Örebro University 2001-03-30, unpublished

[9] R. Kling, H. Crawford, H. Rosenbaum, S. Sawyer, S. Weisband, Learning from Social Informatics: Information and Communication Technologies in Human Context, Center for Social Informatics, Indiana University, USA retrieved from [www.slis.indiana.edu/CSI/2003-12-10 (2000)

[10] P. Aspden, J. Katz, Social and Public Policy Internet Research: Goals and Achievements, Dr Aspen's talk at the University of Michigan School of Information February 2, 1998 retriewed from [www.communitytechnology.org/aspden/aspden_talk.html 2003-12-02

[11] A. Clement, L.R. Shade, The Access Rainbow: Conceptualizing Universal Access to the Information/Communication Infrastruct ure, in Gurstein, $\mathrm{M}$, (ed) Community Informatics: Enabling Communities with Information and Communications Technologies, Idea Group Publishing, London, UK, (2000)

[12] P. Poland, Online Consultation in GOL Countries: Initiatives to Foster E-democracy, Government Online International Network, (2001) http://governments-online.org/articles/18.shtml]

[13] J. Van Dijk, K. Hacker, The Digital Divide as a Complex and Dynamic Phenomenon, The Information Society, 19:315-326, 2003

[14] O. Nilsson, Access Barriers - from a user's point of view, Doctoral thesis, Department of Information technology and Media, Mid Sweden University, Sweden, (2005)

[15] Å. Grönlund,. En introduktion till Electronic Government, in Grönlund, A. \& Ranerup, A.(red) Elektronisk förvaltning, elektronisk demokrati - Visioner, verklighet, vidareutveckling, Studentlitteratur, Lund, Sweden (2001).

[16] Government bill 1999/2000:86, Ett informationssamhälle för alla, Riksdagens tryckeri, Stockholm, (2000)

[17] The Ministry of Industry, Employment and Communications, An Information Society for All - a publication about the Swedish IT-policy, Government Offices of Sweden, (2004) 
[18] E. Boyd, Introduction to the Special Series on the Digital Divide, in Informing Science, vol. 5, No 3, 2002, p. 113-114, (2002)

[19] Carveth, Kretchmer Policy Options to Combat the Digital Divide in Western Europe, in Informing Science, vol. 5, No 3, 2002, p. 115-123 (2002)

[20] J. Israel, Har vi behov? I Aronsson \& Berglind (ed) Handling och Handlingsutrymme, p.51-68, Studentlitteratur, Lund, Sweden (1990)

[21] J. Israel, Handling och samspel. Ett socialpsykologiskt perspektiv, Studentlitteratur, Lund, Sweden (1999)

[22] L. Kvasny, E.M. Trauth, The Digital Divide At Work and Home: The Discourse About Power and Underrepresented Groups in the Information Society, in Wynn, E. Myers, M.D. and Whitley, E.A. Global and Organizational Discourse about Information Technology, pp. 273-291, Kluwer Academic Publishers, Boston, USA (2002)

[23] O. Nilsson, Confidence or Control, in Proceedings of ITiRA 2002 Conference, Rockhampton, Australia (2002)

[24] E. F. Fern, Advanced Focus Group Research, Sage Publications Inc, Thousand Oaks, USA (2001)

[25] K. Lindblad-Gidlund, Techno Therapy, a relation with technology, Doctoral thesis, Department of Informatics, Umeå University, Sweden (2005)

[26] W. Bijker, T. Pinch, The Social Construction of Facts and Artefacts: Or How the Sociology of Science and the Sociology of Technology Might Benefit Each Other, Social Studies of Science, no. 14, (1984)

[27] K. R. Popper, The Worlds 1, 2 and 3, in Popper, K. R. \& Eccles J. C. The Self and ITs Brain, Springer, Berlin, Germany (1977)

[28] World Internet Institute, Virus, spam och tillit, Faktablad nr.1 2005-11-01, retrieved 2005-09-15 at [http://www.wii.se]

[29] EU, elnclusion revisited: the local dimension of the Information Society (2005) [http://europa.eu.int/comm/employment_social/news/2005/feb/eincllocal_en.pdf] 